\title{
THE INTERESTS OF THE CENTRAL ASIAN STATES AND THE SHANGHAI COOPERATION ORGANIZATION
}

\author{
Asist. Prof. Dr. Ezeli AZARKAN, Dicle University, Faculty of Law, Deparment of
} International Law, aezeli@dicle.edu.tr

\section{ÖZET}

Bu makale Şangai İşbirliği Örgütü ( ŞiÖ ) üyesi Orta Asya devletlerinin Örgütün amaçları bağlamında çıkarlarının neler olduğunu araştırmaktadır. Bu çalışma orta asya devletlerinin ŞiÖ'ne üyeliklerinin güvenlik ve ekonomik çıkarları,bölgesel işbirliği ve Rusya, Çin ve Amerika Birleşik Devletleri ile dengeli ilişkiler için yararlı olduğunu göstermektedir.

Orta asya devletlerinin Şiö'ne üye olmakla şu çıkarlara ulaşmaya çalışmaktadırlar: ulus oluşturma, egemenlik ve bağımsızlıklarını dış müdahalelerden korumak, ulusal güvenliklerini sağlamak, iç ve dış tehditlere karşı sınırlarıı korumak, komşu devletler ile iyi ilişikler kurmak, doğal kaynakları üzerinde kontrol sağlamak ve bu kaynakları verimli bir şekilde kullanmak, ticaretlerini geliştirmek, dünya ticaret pazarlarına açılmak, ulaştırma ve haberleşme için ulusal ve bölgesel alt yapının kurulması. Ayrıca, bu devletler bölgesel güvenlik ve ekonomik gelişmenin sağlanması için terör ve uyuşturucu madde kaçakçılığıyla ortak mücadelenin sağlanması içinde şiö'ne ilgi duymaktadırlar.

Anahtar Kelimeler : Orta Asya,Enerji, Güvenlik, Avrasya,SCO.

\section{ABSTRACT}

This article explores the interests of the Central Asian states as members of the SCO, their compatibility with the SCO goals. This study shows that the SCO is compatible with the Central Asian states's security and economic interests, regional cooperation, the need for balanced relations with the great powersChina, Russia and the United States.

The interests of Central Asian members in the SCO can be identified as many: nation building- securing independence, non-interference and sovereignty; national security, protection of borders from internal and external threats; good 
neighbourly relations; control over and effective utilisation of natural resources; enhanced trade and commercial dealings; access to world commodity and capital markets; establishment of national and regional infrastructure for transport and communications. They are clearly most 'interested in the SCO 's practical undertakings for regional security and development such as confidence-building, anti- terrorism activity, fighting drug trafficking.

Key Words: Central Asia, energy,security, eurasia, SCO.

\section{INTRODUCTION}

The Shanghai Cooperation Organization (SCO) is an intergovernmental international organization founded in Shanghai on June 15, 2001 by six member nations: China, Russia, Kazakhstan, Kyrgyzstan, Tajikistan and Uzbekistan. It was established on the foundation of the "Shanghai Five" mechanism, which was initially developed for the purpose of strengthening trust and encouraging disarmament in the border regions of China with Russia, Kazakhstan, Kyrgyzstan and Tajikistan ( Öksüz 2009:715, Kay 2006:159-160 ). The SCO admitted Mongolia into observer status at its 2004 Tashkent Summit and Pakistan, India and Iran received observer status at its 2005 summit in Astana, Kazakhstan. The total area occupied by the SCO member states is about $30,189,000$ square kilometers, or about three-fifths of the territory of Eurasia, with a population of 1.512 billion people, or approximately a fourth of the world's total population ( Brummer 2007: 185 ).

The declared purposes of The Shanghai Convention on Combating Terrorism, Separatism and Extremism are: strengthening mutual trust and good-neighborly relations among member states; promoting their effective cooperation in political affairs, economy and trade, scientific-technical, cultural, and educational spheres as well as in energy, transportation, tourism, and environment protection fields; joint safeguarding and preserving regional peace, security and stability; striving towards creation of democratic, just, reasonable new international political and economic order ( United 2008: 232 ).

However, analyst descriptions of the SCO differ: it is considered by some a security organization, by others a regional economic forum and by others, still, merely an antiterrorism coalition (Gleason, 2005:281). Although, its original focus was regional security and the fight against separatism and extremism, in 2005 the SCO witnessed a shift linked by some analysts to Moscow and Beijing's opposition to American hegemony and wariness about the U.S. presence near their boundaries. The SCO declaration, as well as a bilateral Russo-Chinese declaration on the "World Order in the 21st Century" adopted on July 2, 2005, while not mentioning the United States directly, targeted its perceived domination in international affairs and reiterated the principles of mutual respect for sovereignty and territorial integrity, mutual non-aggression and non-interference (Blagov 2005 ). Furthermore, as other countries in the region expressed their desire to join the SCO a portrayal of the SCO emerged 
as a Russian and Chinese led alliance created to counter U.S. hegemony or as an "Asian NATO" (Cohen 2006:53-53 ). Indeed, if the SCO expanded its membership to include current observer states, Mongolia, Pakistan, India and Iran, the organization would cover almost half the population on Earth. Its members would possess vast energy resources, and include four of the world's nuclear states, and thus could no longer be disregarded as a weak and unimportant consortium.

Many studies on the SCO have treated the Central Asian states as one homogeneous region. This studies will pay close attention to the commonalities as well as differences among the Central Asian states' interests. These nations have, in fact, rarely acted as a coherent union. Although all are governed by authoritarian presidents, the Central Asian states have different strategic interests and have taken different paths to development. They hold conflicting views on the handling of security threats, which are often informed by the degree of openness tolerated by their regimes.

\section{THE CENTRAL ASIAN STATES AND THEIR SIGNIFICANCE}

In order to understand the significance of Central Asia and its importance in the new world order, each state's geographic location, population and economy must be examined. Hence, there will be an overview of these topics for the four Central Asian countries that are part of the SCO. This overview will be followed by a discussion of the significance of the Central Asian space in the post-Cold War era. For the purposes of this essay the Central Asian states will refer to Kazakhstan, Kyrgyzstan, Tajikistan and Uzbekistan, but not Turkmenistan, because it is not a member of the SCO. This chapter will also examine the origin of the SCO, why Uzbekistan did not join until 2001, and why Turkmenistan is not a member of the SCO.

\section{ESTABLISHMENT OF THE SHANGHAI COOPERATION ORGANIZATION}

The SCO stemmed out of its predecessor, the Shanghai Five forum, which convened in 1996 at the initiative of China with the purpose of settling the border disputes with the newly independent former Soviet republics of Russia, Kazakhstan, Kyrgyzstan and Tajikistan. In contrast to the SCO, the Shanghai Five was a very straightforward group that achieved its initial goals. At the first Shanghai Five Summit in April of 1996, the five member nations developed security confidence-building measures in the border areas before the final resolution of the border problems. In particular, they agreed that their military forces would not to engage in any offensive activities within the border areas; that they would not conduct military exercises against each other; that they would limit the scale, level and frequency of military exercises in the border areas; inform each other about their respective major military activities in the areas within one hundred kilometers from the borders; invite each other to 
observe their planned military exercises; prevent dangerous military activities in the border areas; and enhance friendly exchanges between the military forces and border patrol forces along the border areas (Wang- Zheng 2008: 241-250).

Following this summit, China and Kyrgyzstan signed a border agreement in July 1996, which was ratified in 1999 and finally approved by the Kyrgyz parliament in 2002, thus settling problems along 858 kilometer long border between them (Kellner 2004: 42 ) . By the year 2000, the Shanghai Five members agreed to deepen multilateral cooperation in the spheres of regional security, politics, economics and trade. Moreover, at the Dushanbe summit, where Uzbekistan participated as an observer for the first time, they signed a declaration endorsing China's and Russia's positions on a multi-polar world, an Anti-Ballistic Missile treaty, and opposed the United States' plan to build a National Missile Defense system in the Asia Pacific region. In addition, they vowed to defend the goals and principles of the United Nations Charter, and reiterated that countries have the right to choose political, economic and social development models according to conditions in their respective nations. In 2001, China and Tajikistan successfully concluded an agreement that permanently settled the remaining disputes along their common borders, and Uzbekistan gained membership at the SCO (Kellner 2004: 43-44).

The organization expected to be an example of a new type of organization vowing to promote a new international political and economic order, featuring democracy, justice and rationality(Kellner 2004: 43 ). However, the organization continues to be shrouded in mystery and full of contradictions and controversies. Every year the SCO gains more attention from the West, especially with the start of the U.S. intervention in Afghanistan and with the rising interests from other countries in the region to join. Indeed, the SCO currently has four observer states: Mongolia, Iran, India and Pakistan. Also, there has been some talk of the possible inclusion of Turkmenistan, if the country wishes to join.

The question arises as Turkmenistan, which has geographic proximity and similar concerns as other Central Asian states, has not joined the SCO? First, it does not share any borders with China, hence it was not part of the Shanghai Five. Second, since its independence Turkmenistan's foreign policy has been that of neutrality and isolationism. Moreover, Turkmenistan has been hesitant to sign economic agreements within the CIS framework as President Niyazov has criticized the weakness of CIS mechanisms. However, after the death of President Niyazov in 2006, some analysts believe that this could change. Indeed, the new Turkmen President Berdimukhamedov has been more engaged in international relations and attended the 2007 SCO summit as a guest of honor.

The question as to why Uzbekistan did not join the Shanghai Five is a salient one as well. Uzbekistan was not a party to this forum from the beginning because, first, it does not share any borders with China, and second, in 1996 
Uzbek President Karimov began a policy of aggressive protection of sovereignty and distanced himself away from Russia and the Commonwealth of Independent States (CIS). Uzbekistan voiced opposition to CIS centralization as well, saying that Uzbekistan's government would not hand over its sovereignty to supranational CIS institutions ( Splidsboel-Hansen 2000:98 ). Instead, Karimov was hoping to gain closer ties with the United States, and thus Uzbeksitan joined the NATO Partnership for Peace (PfP) program in 1994 and the U.S. backed GUAM - Organization for Democracy and Economic Development in 1999. However, as the Uzbek president was facing increasing disputes among regional elites within his country and not getting the desired help from the United States in strengthening his position, he accepted the invitation to join the SCO in 2001. As a result, in 2001 the Shanghai Five became the Shanghai Cooperation Organization and expanded its goals to encompass issues concerning security, economic, political, regional peace, education, cultural exchange, and environmental protection.

\section{GEOGRAPHIC AND ECONOMIC OVERVIEW OF THE CENTRAL ASİAN STATES}

Kazakhstan borders China $(1,533 \mathrm{~km})$ in the east, Kyrgyzstan $(1,051 \mathrm{~km})$ and Uzbekistan $(2,203 \mathrm{~km})$ in the south, Russia $(6,846 \mathrm{~km})$ in the north, and Turkmenistan $(379 \mathrm{~km})$ in the west. Kazakhstan is landlocked, bordering two inland seas, the Aral and the Caspian Seas and has the largest and fastest growing economy among all the Central Asian states, with a GDP of \$ 105 billion and a population of 15,480,000 (The World Bank 2009 ). It holds abundant supplies of minerals and metals such as coal, iron, gold and uranium and most importantly vast reserves of natural gas and petroleum, about one percent of the world's total reserves. Extraction of the hydrocarbon reserves accounts for most of the country's industry. Its agricultural sector consisting of livestock, cotton and grain production, accounts for a small portion of the country's GDP ( Porter 2005 ).

Since the collapse of the Soviet Union in 1991, demand for Kazakhstan's traditional heavy industry products resulted in the short-term contraction of the economy, with the steepest annual decline occurring in 1994. In 1995-1997, the government carried out economic reforms and privatization, which resulted in a substantial shifting of assets into the private sector (Zardykhan $2002: 173-174$, Blackmon 2005 : 393 ). Since 2000, Kazakhstan has experienced over nine percent growth rate, largely due to its booming energy sector, but also modest economic reform, good harvests, and foreign investment. Currently the country has adopted an industrial policy designed to diversify the economy away from overdependence on the oil sector by developing light industry. The policy aims to reduce the influence of foreign investment and foreign personel (LeeKolesnikova $2009: 131$ ).

Kyrgyzstan borders China in the east, Kazakhstan in the north, Tajikistan in the south, and Uzbekistan in the west. Kyrgyzstan is also a landlocked country. The 
second poorest country in Central Asia with a GDP of $\$ 2.14$ billion, it has a population of 5,5,213,898 (U.S. Federal Research Division 2007 ). Having a predominantly agrarian economy, its main agricultural products include cotton, tobacco, wool, and meat. Industrial exports include gold, mercury, uranium, natural gas, and electricity. After the collapse of the Soviet Union, Kyrgyzstan distinguished itself from other Central Asian state by adopting relatively liberal economic policies, hence Kyrgyzstan was the first CIS country to be accepted into the World Trade Organization (WTO) in 1998. Kyrgyzstan was progressive in carrying out market reforms, such as a privatization and land reform ( Hanks 2005:341). By 2003, 7,000 enterprises had shifted to the private sector. However, the rate of privatization slowed due to domestic opposition and low foreign investment. Two years later, in 2005, at the suggestion of international institutions, Kyrgyzstan agreed to pursue tax administration reforms. Kyrgyzstan needs to continue to create more favorable conditions for foreign investment, as this would greatly boost the country's income. Indeed, Kyrgyzstan has great potential for developing a thriving tourist industry and is sometimes referred to as Asia's Switzerland because of its beautiful mountain ranges. Another potential great source of income is the country's abundant hydroelectric power.

Tajikistan borders China in the east, Afghanistan in the south, Kyrgyzstan in the north, and Uzbekistan in the west. Tajikistan has a GDP of $\$ 1.89$ billion, the lowest among the Central Asian states, and a population of 7,320,815.29 (U.S. Federal Research Division 2007 ). Although only six percent of its land area is arable, it is predominantly an agrarian economy, with cotton as its main agricultural product.. Tajikistan possesses limited amounts of various mineral resources such as silver, gold, uranium, and tungsten. Its industry sector consists of hydropower plants, one aluminum plant, and a number of small obsolete factories in light industry and food processing. Tajikistan's weak economy suffered further damages from the civil war in the mid-1990s. Today, sixty four percent of people in Tajikistan live in deep poverty, largely dependent on foreign aid. Nonetheless, Tajikistan has experienced economic growth since 1997, with a slight drop in its growth rate to eight percent in 2005 from over ten percent in 2004 (Asian Development Bank 2005 ). In December 2002, Tajikistan reached a significant debt restructuring agreement with Russia, wherein the latter agreed to write-off $\$ 250$ million of Tajikistan's $\$ 300$ million debt.31 Tajikistan ranks third in the world in terms of water resources per capita and is continually seeking foreign investment to revive its hydropower sector. In 2005, Russia pledged to invest $\$ 500$ million into construction of Sangtuda. Another current project is the hydropower dam, Rogun, possibly the world's tallest dam (Asian Development Bank 2002 ).

Uzbekistan borders Afghanistan in the south, Kazakhstan in the northeast, Kyrgyzstan in the east, Tajikistan in the southeast, and Turkmenistan in the southwest. Uzbekistan has a GDP of $\$ 10.7$ billion and a population of 26.845.000 ( Republic ). Uzbekistan is the world's second-largest cotton exporter and fifth largest producer; it relies heavily on cotton production as the major source of export earnings, a legacy of the Soviet Union. Other major 
exports include gold, petroleum, and natural gas (the world's thirteenth-largest producer). Following independence in September 1991, the government continued with a Soviet-style command economy with subsidies and tight controls on production and prices. While aware of the need to improve the investment climate, the government still sponsors measures that often increase, not decrease, its control over business decisions. A sharp increase in the inequality of income distribution has hurt the lower ranks of society since independence ( Blackmon 2005: 396 ). During the seven lean years of inconvertibility, 1996-2003, bureaucratic controls impaired Uzbekistan's economy. Many people, particularly European minorities, complained of a worsening economic situation (Radnitz, 2006). Others, especially Uzbekistanis from environmentally afflicted Karakalpakstan and the depressed Fergana Valley, found seasonal work in southern Kazakhstan and Siberia, and have continued to do so. About 85,000 Uzbekistanis emigrated permanently in 2003 , according to official figures (Paramonov, 2006). Small businesses multiplied, as everywhere else in the region, but were subject to arbitrary and discriminatory taxes (Verme, 2006) and even takeovers by privileged individuals.

In 2003, the government accepted the obligations of Article VIII under the International Monetary Fund (IMF), providing for full currency convertibility. However, strict currency controls and tightening of borders have lessened the effects of convertibility and have also led to some shortages that have further stifled economic activity. The Uzbek Central Bank often delays or restricts convertibility, especially for consumer goods. Potential investment by Russia and China in Uzbekistan's gas and oil industry would increase economic growth prospects.

\section{SIGNIFICANCE OF THE CENTRAL ASIAN REGION}

It is evident from the economic overview above that neither Central Asia's population, of about fifty five million people, nor its economic capacity, with a total GDP of about $\$ 62.43$ billion, represents a considerable impact on the world. However, its energy resources are clearly significant and its location is strategically important. Located at the center of Eurasia on the intersection of critical transport routes, Central Asia represents a strategic component of the Eurasian continent. These four former Soviet republics of Central Asia serve as a bridge between East and West ( Rumer $1996: 1$ ). As a special report from The Economist noted: "They are flanked to the east by a rising great power (China); to the North by their former hegemon (Russia); to the south by a country collapsed in violent chaos (Afghanistan), a fundamental Islamic republic (Iran), and a brittle secular state in search of a greater regional role (Turkey). Along with these, a distant superpower seeks influence, if not dominance ( US ) "(Beddoes 1998 ).

Indeed, since the September 11, 2001 terrorist attack in the United States, the Bush administration has viewed the Central Asian states, particularly Uzbekistan, as vital partners in the American-led "Global War on Terrorism". 
Uzbekistan was the first Central Asian country to offer the use of its bases, which are far more modern and secure than the bases at Bagram and Kandahar in Afghanistan, where more than two decades of war have left them less suitable for twenty first-century airborne military missions. Moreover, Central Asia is a major transit route for opium from Afghanistan to Russia and Western Europe. Furthermore, Central Asia has the leftovers of military industries of the former Soviet Union that could easily get into the hands of terrorist or rogue states.

Finally, the abundance of untapped energy resources has attracted the attention of China, Russia, the European Union, and the United States, although the Central Asian oil and gas are useless unless they can be brought to the market, a difficult challenge in an entirely landlocked part of the world. Hence, it is the route of potential export pipelines that will most likely determine regional alignments and outside influence. For decades, Russia has controlled most export routes, and thus has a stranglehold in the region; but as China, the European Union and the United States bring significant investments to fund transit and transport infrastructure, Russia's influence is challenged. Many analysts, in fact, have proposed that a new "Great Game" is taking place in this region, with the major players being China, Russia and the West.

\section{THE INTERESTS OF THE CENTRAL ASIAN STATES AND THE SCO}

Since the breakup of the Soviet Union, the Central Asian states have been facing common development problems: slow transition toward democracy, concern over Islamic radicalization, the proliferation of weapons of mass destruction, narcotics trafficking, lagging implementation of market-oriented economic reforms, poor business and investment climates, widening income disparities, and pervasive poverty. Shared challenges - including combating terrorism and transnational crime, improving border management, achieving economic diversification, increasing intra-regional trade, accessing world markets, and making more sustainable use of natural resources - have presented opportunities for developing mutually beneficial relations. Indeed, several attempts were made for institutionalizing formal cooperation within the region such as Central Asian Economic Community (CAEC) in 1994, Central Asia Regional Economic Cooperation (CAREC) in 1997, Eurasian Economic Community (EurAsEC) in 2000, and the Economic Cooperation Organization (ECO). Most of these efforts, however, failed to achieve the initially set goals due to the rivalries, tensions and imbalances among the states in the region. Similarly, the effectiveness of the SCO until the June 2004 summit, had been limited because Central Asian states were reluctant to abandon their multidirectional foreign policies geared to gaining maximum advantage by playing off the West, particularly the United States, against the developing China-Russia axis. 
The picture changed in 2004 and 2005 as the result of successful "color revolutions" in the former Soviet republics of Georgia and Ukraine, and, most importantly, Kyrgyzstan, which awakened Central Asian leaders - including the new regime in Kyrgyzstan, which faces determined opposition - to their vulnerability. Realizing that the United States and Western Europe were seeking to establish pro-Western marketoriented regimes as replacements to the authoritarian, clan-based and crony systems currently in place in the region, Central Asian leaders began to perceive that multidirectionality might be unrealistic, and moved to strengthen their relations with Moscow and Beijing through the SCO. From the Central Asian states' perspective, the creation of the SCO could potentially satisfy four important needs. First and foremost, the organization helps to maintain the political balance between Central Asia's two most powerful and influential neighbors, China and Russia, and to restrain Uzbekistan's ambitions of regional hegemony. Second, the SCO could provide desperately needed regional security and stability. Third, the SCO could provide with greater economic cooperation and aid, particularly assistance in the development of Central Asian energy resources, and through increased trade and direct investment from Russian and Chinese firms. Forth, the SCO could support the Central Asian regimes' survival or preservation of the status quo. In its goals, the SCO has strongly stressed the value of "non-interference" in a sovereign nation's internal affairs, hence satisfied the interests of the leaders of the Central Asia states. Finally, the SCO could help increase regional cooperation in general and on issues of water distribution and border disputes in particular.

\subsection{Security Concerns}

Historically, dating to its conquest by the Russian tsar in the late 19th century, the Farghona Valley has been the region where Islamic militants have been most active. The Farghona Valley, where the Kyrgyzstan, Tajikistan and Uzbekistan borders meet, has been the scene of political violence in the region and a source of constant tension between the three countries. It is here that the Islamic Movement of Uzbekistan (IMU) emerged in 1998 out of an Islamic group, Adolat (Justice), which was based in the Uzbek city of Namangan at the time of the Soviet dissolution. In late 1991, Adolat seized effective control of the local government in Namangan, emphasizing its ability to stamp out crime and official corruption in the city (Bowers 2006:377 ). Within a year, Uzbekistan's President Karimov ordered a crackdown, which led to the mass arrests of men in Farghona Valley. Those who managed to flee ended up fighting alongside Islamists in the Tajik civil war or the Afghan civil war. By 1997, with the Tajik civil war winding down and the Taliban in control of Kabul, the IMU became increasingly active in the Farghona Valley, aiming to topple the regime of Karimov and to replace it with an Islamic state in Uzbekistan ( Bowers 2006:376).

Most of the IMU's fighters were based in Afghanistan, where they were given refuge by the Taliban as well as training, funding, and military supplies from al- 
Qaeda. In October 2001, during the U.S.-led invasion of Afghanistan, one of the IMU leaders, Juma Namangani was killed and another, Tohir Yoldashev, led an estimated 250 Central Asian families to Pakistan's North-West Frontier Province where the central authorities traditionally have little power (Schri 2005 ).

The second radical Islamic group vying for control of Central Asia is the pacifist Hizb ut-Tahrir al-Islami (The Islamic Party Liberation, also known as HuT). It shares similar goals with the IMU, i.e. creating a Muslim state encompassing all of Central Asia, including the Xinjiang Province of China, and eventually incorporating the entire Islamic world community under a new caliphate. However, the HuT believes in achieving these goals by peaceful means (Collins 2007: 69 ). Nevertheless, Karimov has blamed this radical group for organizing the popular unrest and protests in Andijon, Uzbekistan in May of 2005. The Andijon protests started in response to the trial of twenty-three local businessmen accused of Islamic extremism. The families of the accused had been protesting peacefully throughout the four month-long trial, but on May 12 some of them were arrested. Their incarceration lead to the storming of the jail by a few gunmen and freeing of the businessmen and their families as well as some other inmates and the take over of the area and local government offices. As the local population learned of these happenings about ten thousand farmers, women, and children poured in to the main square to discuss and speak out against injustices, human rights abuses, and poor economic conditions in the country (Kendzior 2006: 554-555). The protest did not last long before the Uzbek security forces arrived in armored vehicles and started to shoot at the protestors. It was estimated that the casualties ranged from 187 (according to Uzbek officials) up to 500 (according to Amnesty International) (Amnesty International 2006).

Tajikistan's relations with Islamic fundamentalist groups differ from those of other Central Asian states. After the collapse of the USSR, and as Central Asia experienced a revival of Islam, Tajikistan was moving toward a multi-party system. Out of this environment, the Islamic Renaissance Party (IRP) emerged, with the goal of reviving Islam after its erosion during the Soviet era. In 1991, the IRP and the Democratic Party put forth one candidate in presidential elections, but lost to the Communist Party's Rakhmon Nabiev ( Collins 2007:85). This election brought about civil unrest as a result of which Nabiev resigned in 1992. The power struggle between different regions of the country led to the Tajik civil war (1992-1997), in which at least 50,000 people were killed. The War completely destroyed the Tajik economy and left its population the most armed and militarized in the region (McGlinchey 2005: 338 ). In 1996, the acting President Emomali Rahmonov, who was the chairman of People's Democratic Party, signed a peace agreement with the United Tajik Opposition (UTO), which consisted mainly of IRP, democrats, liberal, and reformists( McGlinchey 2005: 338 ). This agreement has enabled Tajikistan to be the only Central Asian state with an active Islamic party in the government and the IRP the region's only Islamist movement participating in the political life of a secular state. 
Kyrgyzstan, having similar security concerns of terrorism and Islamic extremism, is more tolerant of Islam than Uzbekistan and Kazakhstan, although it does not have an active religious party participating in its secular government like Tajikistan does. For instance, Kyrgyzstan law allows women to wear a veil if they choose to, whereas Uzbekistan forbids it. However, Kyrgyzstan condemns radical Islamic groups.

Finally, in Kazakhstan the 1993 constitution specifically forbade religious political parties. The 1995 constitution forbade organizations that seek to stimulate racial, political, or religious discord, and imposes strict governmental control on foreign religious organizations. Thus, Kazakhstan is the only Central Asian state whose constitution does not assign a special status to Islam. Although Islam is the most widely practiced religion today among the Kazakhs, it does not have a long tradition as it does in Uzbekistan and Tajikistan; hence, Kazakhstan does not appear to have any homegrown radical Islamic groups.

Regional stability is of utmost importance to all the countries in the region, hence fight against terrorism and religious extremism is one of the primary goals of the SCO. Since 2001, the SCO has held meetings on how to solve this problem, and it finally in 2003 created the Regional Anti-Terrorism Structure (RATS), which is based in Tashkent, with the main function of coordinating SCO member activities to combat the "three evils", i.e. terrorism, separatism, and extremism. Member states decided to hold regular meetings of the defense ministers at the Bishkek summit, but there is little information on the outcome of such meetings(Öksüz $2009: 718$, Chung 2006: 3 ). Since the establishment of RATS, its member states held a number of joint antiterrorist exercises within the framework of the SCO. the SCO members conducted the "Cooperation 2003" joint command-post exercises combined with field maneuvers. The first stage of the operation was held in Kazakhstan, where Russian, Kazakh and Kyrgyz troops participated; the second stage was held in the Xinjiang province of China, involving Chinese and Kyrgyz troops ( McDermott 2003 ). Another joint antiterrorism military exercise within the framework of the SCO took place in August of 2007. The Peace Mission 2007 maneuvers began in China's western Xinjiang Uyghur Autonomous Region and then moved to Russia's Chelyabinsk Oblast. Some 6,500 troops from all six member-states participated in the six-day drill, and eighty warplanes and combat helicopters were mobilized in the SCO's largest counterterrorist exercise ( Pannier 2007).

The second destabilizing factor in the region after terrorism and religious extremism is drug and arms trafficking and related organized crimes. Central Asia is a major "highway" for narcotics gangs to transport their products from Afghanistan to European and Russian markets. The U.N. Office for Drug Control and Crime Prevention estimated that that ninety two percent of the world's heroin comes from Afghan poppies (World Drug Report 2008 ). In 2006, onequarter of Afghan opiates was believed to have been trafficked through the Central Asian countries (mainly Tajikistan) (World Drug Report 2008 ). What is more, profits from the narcotics trade are the primary source of funding for the 
militant Islamic groups. Despite the defeat of the Taliban in Afghanistan, drug trafficking is on the rise. In 2002 alone, the United States committed close to $\$ 100$ million to counter-narcotics trafficking programs in Afghanistan and Central Asia, and an army of United States, international and local Central Asian officials and specialists have been tasked to fight this trade (Lubin 2004:362 ).

The SCO considers "protection of peace and stability in the region and the promotion of economic cooperation as its primary task, and attached great importance to cooperation in the fight against narcotics". Consequently, in 2005, in response to the growing specter of drug-trafficking and related crimes, the SCO launched the SCO Afghanistan Contact Group. At the 2007 SCO summit, Russia's president suggested forming anti-drug security belts around Afghanistan, which were to be complemented with financial security belts that would be supervised by the SCO financial monitors. However, there is insufficient data to show that noticeable results have come out of these agreements.

\subsection{Preservation of Current Regimes}

The Central Asian states remain autocratic regimes, despite their leaders' expressed commitment to democratic government in their respective countries. For instance, during his 1994 visit to the United States, Kazakh President Nazarbaev signed a Charter on Democratic Partnership recognizing his nation's commitments to the rule of law, respect for human rights, and economic reform, which he repeated in 2001 in a joint statement with President Bush. In 2002, a U.S.-Uzbek Strategic Partnership Declaration was signed pledging Uzbekistan to "intensify the democratic transformation" and improve freedom of the press. During his 2002 visit to the United States, Tajik President Rakhmanov pledged to "expand fundamental freedoms and human rights." ( Nichol 2006 ). However, there is little evidence to suggest that these pledges are more than ceremonial. According to Freedom House, in 2005, Uzbekistan placed along Turkmenistan and six other nations (Burma, Cuba, Libya, North Korea, Sudan, and Syria) as the world's most repressive regime ( Freedom House Press 2006 ), although the Central Asian states have poor records of human rights. Corruption is widespread and commonplace. Elections in these countries are often fraudulent with the incumbent carrying the overwhelming majority of the votes; as a result, Kazakh, Tajik and Uzbek leaders have been in power for over a decade and a half. There are no independent and fair court systems in these states; in fact in Uzbekistan conviction rates approach one hundred percent and outcomes of court cases are usually predetermined, and Kazakhstan uses its court system to dispose of President Nazarbaev's political rivals. There is no independent media in Uzbekistan, while Kazakhstan, Kyrgyzstan and Tajikistan impose great restrictions on their respective media outlets. Although the constitutions of these countries allow for religious freedom, there are frequent repressions of Muslims and Christians, especially in Uzbekistan. 
Nonetheless, the seeming invincibility of the authoritarian rulers of Central Asia was shattered with the beginning of the color revolutions that facilitated peaceful transition of power from authoritarian rulers to democratic governments in Georgia (2003) and in Ukraine (2004). The success of the Rose Revolution in Georgia and Orange Revolution in Ukraine in sweeping away ex-communist authoritarian regimes has raised the prospect - even the expectation - that this might occur in the rest of the Central Asian states ( Katz 2006 ). When the Tulip Revolution swept across Kyrgyzstan, in the spring of 2005, authoritarian President Askar Akaev fled the country, and Kurmanbek Bakiev, who advocated democratization, was elected the second president since independence. Consequently, the Kazakh, Tajik and Uzbek leaders took immediate actions to stop the spread of this process in their countries.

On of their first steps was to repress U.S. and western NGOs such as Soros Foundation - the largest U.S. private donor in Central Asia. The U.S. and European NGOs, working on creating civil societies in Central Asian counties, were accused of supporting and even planning the revolutions in order to serve western interests (Ruffin 1999:22 ). Consequently, Karimov's regime closed down approximately 200 domestic nonprofit organizations in Uzbekistan and forced a number of international NGOs such as the Open Society Institute (OSI) to leave the country. In 2006, after the Andijon killings, the United Nations' refugee agency was expelled from Uzbekistan and international media outlets, including the BBC, Internews and RFE/RL closed their offices due to harassment received from the Uzbek government ( Krastev 2006 ). In Tajikistan, state-controlled media campaigned against OSI-Tajikistan accusing it of corruption and nepotism; fortunately, the organization has been allowed to continue their activities. Even in Kazakhstan, where the press has enjoyed some freedom and the NGOs have operated without significant interference, as a result of social unrest linked to the color revolutions the government launched a criminal case against the Soros-Kazakhstan Foundation for tax evasion and introduced new legislation that continues to severely limit the rights of politicians to register as candidates, the right of people to demonstrate, and the rights of NGOs to operate freely ( Saidazimova 2004 ).

Furthermore, the Uzbek president, who was the United States' closest ally in Central Asia during military operations in Afghanistan, evicted U.S. forces from the Karshi-Khanabad base, after the U.S. Department of State had criticized the Uzbekistan government's handling of the 2005 Andijon uprising. With the color revolutions sweeping across post soviet states, Central Asian leaders cooled their relations with the United States, fearing the intrusion of democratic values, and turned closer towards their SCO partners - China and Russia - who supported current leaders and regimes and opposed interference in other country's domestic affairs The SCO prides itself on wanting to become a modern organization of a new type in line with the demands of multi-polar world. Indeed, many analysts believe the SCO has become a tool of the Chinese and Russian governments intended to weaken American opportunity to interfere in their own internal affairs and to create a multi-polar world in the post-Cold War 
era ( Blagov 2002 ). In this respect the goal of China and Russia is in line with the Central Asian leaders' interests of preserving their regimes. Some analysts have attributed the Tulip Revolution in Kyrgyzstan to clan and regional fighting rather than characterizing it as a democratic movement. Clan and regional fighting have caused a great deal of instability in Central Asia. For instance, the Tajik civil war broke off between the disenfranchised groups from the Pamirs, Garm and Gorno-Badakhshan regions and the national government supported by the traditional northern economic elite of Khujand, the Kulyab and KurganTube and ethnic Uzbeks from Hissar region. The former were a coalition of liberal reformists, self-declared democratic and Islamic groups who were traditionally underrepresented among the ruling class during the Soviet and preSoviet control. The SCO members value regional stability by any means for the sake of economic development, hence power struggles among the Central Asian elites were denounced. Both Russia and China have pledged to help Kyrgyzstan to restore order under their SCO commitments ( Daly 2005 ).

\subsection{Economic Needs}

Central Asian states are endowed with abundant natural resources: Kazakhstan and Uzbekistan have great hydrocarbon reserves and Kyrgyzstan and Tajikistan have vast water resources for producing cheap electricity and good potential for renewable energy development. However, outside assistance is needed to create an infrastructure to facilitate production and transport of these products to international markets. Kazakhstan's oil reserves are estimated at 9 and billion barrels ( Kandiyoti 2008 ). There are four main oil fields in Kazakhstan: Tengiz, Uzen, Karachaganak, and Kashagan. The Kashagan field has received much recent attention after preliminary drilling and exploration; however, the project has been delayed due to complicated natural and geological conditions and estimated development costs of $\$ 29$ billion dollars. Analysts called Kashagan the largest oil discovery of the past thirty years. Kazakhstan also has sixty-five to one hundred trillion cubic feet (Tcf) of natural gas reserves associated with its oil production. However, the pipeline infrastructure for moving the gas is lacking and some of the gas is being flared. The main area for current natural gas production is the Karachaganak field in northwest Kazakhstan, which contains more than twenty percent of Kazakhstan's total reserves. Kazakhstan is also planning to develop the Amangeldy field with an estimated gas reserve of 1.8 Tfc in the southern part of the country.

Kyrgyzstan's tremendous reserve of fresh water makes it one of the richest states in the world for such natural resources. Kyrgyzstan's total flow of water resources comprise approximately fifty one billion cubic meters per year. The Kyrgyz energy system has eighteen power plants over the Naryn and Syr Darya rivers with a total installed capacity of 3,678 megawatts (MW). Completion of the construction of the Kambaratin Hydroelectric Power Plants 1 and 2 would increase generating capacity by $2,260 \mathrm{MW}$ and the volume of annual generation of electricity by more than six billion kilowatt hours (KWh) (Sakiev 2006). This country also has a great potential for tourism development. 
Tajikistan is also rich in water resources and holds the eighth highest concentration of hydropower resources in the world. While Tajikistan has the potential to produce more than 300 billion KWh electricity per year, it currently produces only 17.1 billion $\mathrm{KWh}$. The majority of Tajikistan's hydroelectric energy is produced by the hydroelectric stations on the Vakhsh River, with a total capacity of about $3,800 \mathrm{MW}$, producing forteen billion $\mathrm{KWh}$ annually. The largest of these is the Norak hydroelectric facility, which is rated at 3,000 MW. An even larger facility at Rogun, expected to be 335 meters high and the tallest dam in the world, is under construction and will have a capacity of 3,600 MW. Construction of Rogun began in 1976, and by 1996 over $\$ 802$ million had been invested. Completions of Rogun will required an additional $\$ 2.2$ billion (Zarifi ( 2007 ). Tajikistan also has great potential for a tourism industry; with its geographical terrain, suitable for climbing and ecological tourism, and its ancient structures lending itself to historical and archeological tourism.

Uzbekistan currently possesses 594 million barrels of proven oil reserves, which is soon expected to increase, and estimated natural gas reserves of 66.2 Tcf. There are 171 oil and gas fields accounting for about seventy percent of Uzbekistan's oil production. Most of these are located in the Bukhara-Kiva region. The second richest region in hydrocarbon reserves is the Farghona Basin containing about twenty percent of Uzbekistan's oil fields. There are also oil deposits being developed in southwestern Uzbekistan at Kokdumalak, Shurtan, Olan, Urgin, and south-Tandirchi. The Ustyurt plateau and the Aral Sea are also under investigation as potential oil fields. There are a total of fifty-two fields in the Ustyurt region, representing ninety five percent of Uzbekistan's natural gas reserves. Developments at existing fields, such as Garbi and Shurtan are underway, as is exploration of new fields and reserves(U.S. Energy Information Administration May 2009 ). However, to reap the benefits of their natural resources, these countries need outside assistance in developing infrastructures.

In 1991 when the Soviet Union collapsed, the economies of these countries experienced severe contraction and in seventeen years not much progress has been made, except for Kazakhstan, whose economy has been enjoying nine to ten percent growth rates since 2000 aided by the increased oil prices on the international markets. Although Central Asian leaders have stated their commitment to a gradual transition to a free market economy, they have been slow at introducing market reforms and privatization, with Uzbekistan being the slowest reformer and Kazakhstan and Kyrgyzstan leading the way. The investment environment is hostile to foreign direct investment, including unfair trade practices, high import barriers, and high taxes. In addition, high levels of corruption throughout all echelons of government and lack of rule of law have kept foreign companies away from Central Asia. In Kyrgyzstan, Tajikistan and Uzbekistan, large foreign debt has also kept the economy from expanding. 
Kazakhstan has taken the biggest steps in implementing market reforms and privatization was able to repay its debt to IMF in 2000, seven years ahead of Schedule (Pomfret 2005 ). However, it is not clear whether these reforms or the increased oil prices enabled Kazakhstan to achieve such success, as Kyrgyzstan also implemented comparable reforms, but having a poor resource base, has not been as successful.

The Central Asian states have not been able, on their own, to address their biggest problem, i.e., the transportation and communication links across the difficult terrain. It is a daunting task to build roads, railways, and pipelines through some of the highest mountains in the world, across deserts, and on the vast steppes. To this extent, there have been many initiatives to address these interests within the framework of the SCO.

In 2003, the SCO members discussed a multilateral agreement on auto transport and the joining of SCO member states to the European highway transport agreement. in 2006 Tajikistan officially launched the reconstruction of the Dushanbe-Chanak highway, a project estimated to cost some $\$ 296$ million, $\$ 281.2$ million of which would be financed by a long-term loan from China. The highway running from Kulma (south-east Tajikistan on the Chinese border) will link Horog-Darvaz-Kulyab-Dushanbe and the Dushanbe-Hujand-BustonChanak highways. Another project underway is the Tajik-Uzbek highway, which would link China, Kyrgyzstan and Uzbekistan and is expected to be operational in 2008.

In 2004, negotiations for intergovernmental agreement on facilitating international road transport with the support of the U.N. Economic and Social Commission for Asia and the Pacific and the Asian Development Bank (ADB) ( Asian Development Bank 2005 ). At the 2006 Dushanbe Summit, member states signed a communiqué that stated "the SCO's priorities in the near future will be energy, transportation, and telecommunications." (the Organisation's web site http://www.sectsco.org Accessed April 2009 ).

This communiqué also spoke of the impending creation of the "energy club," which was proposed by the Russian president. The aim of this club is to bring together major energy producers and key consumers within the ambit of the SCO, which would lead to the coordination of efforts in joint energy production and transportation projects ( Haas 2007 ). The SCO is also cooperating with the United Nations Development Program on the Silk Road Initiative that aims to enhance regional cooperation and development by improving policy and legal conditions for trade, initiating and attracting investment, and promoting and attracting tourism. Also, in 2006 member states started the establishment of the SCO Development Fund, for the purposes of sponsoring multilateral development programs similar to the U.N. development programs. However, Russia rejected this idea, as it did not wish to contribute state funds to it, while at the same time, it was worried that China, who was ready to put up money, would control the fund (Lukin 2007 ). 
Therefore, two non-governmental institutions - the SCO Business Council and SCO Interbank Association - were established to facilitate development of economic partnership within the SCO framework. Additionally, a number of agreements was signed: the 2001 Memorandum on the Main Goals and Areas of Regional Economic Cooperation, the 2003 Program for Multilateral Trade and Economic Cooperation until 2020, the 2004 plan of actions for implementing this program and the 2005 Mechanism for Implementing the Plan of Actions.. Furthermore, the Central Asian states, through cooperation with SCO members, could gain access to seaports, a significant benefit, as all of these countries are landlocked (in fact, Uzbekistan is doubly landlocked).

\subsection{Regional Cooperation}

In the early stages of their independence, with the dissolution of the Soviet Union, the Central Asian states had an opportunity to establish a functioning union that could have benefited the people of this important region. The common Soviet past as the basis of economic and social development, the Russian language as a common language, economic similarities, similar historical experiences, and related cultures could have served as the basis for the creation of an economic union in Central Asia but early attempts were ultimately not sustainable. Such an attempt was first made in 1994 under Kazakhstan's leadership: the Central Asian Union, formed by Kazakhstan, Kyrgyzstan and Uzbekistan with the aim of creating a single economic region with improvements in payments arrangements and reduction in tariffs among member countries. In 1995, the principle of free trade among member states was approved and a Central Asian Bank for Co-operation and Development was created. In 1998, Tajikistan joined this organization and it became a CAEC. In 2001, the CAEC was transformed into the Central Asian Cooperation Organization (CACO) with the aims of expanding cooperation in economic and political spheres, as well as of creating consortia to deal with issues such as water and energy resources.

Nevertheless, regional cooperation is largely lacking, as Central Asian governments fear that closer economic ties and integration with their neighbors may arouse border disputes. Ongoing border disputes remained a serious issue among the Central Asian states. Border resolutions were a primary reason for the assembly of the predecessor of the SCO, the Shaghai Five, back in 1996, at China's request. Indeed, by now all disputes have been settled between China and the Central Asian states, but there are a number of disputes open between Kazakhstan, Kyrgyzstan, Tajikistan and Uzbekistan. Many of the current difficulties can be traced directly back to the early years of the Soviet era. In the mid- 1920s, Joseph Stalin established the administrative borders of its Central Asian republics, which purposefully followed neither natural geographic boundaries nor strict ethnic lines in order to avoid drawing more homogeneous or compact republics for fear they would stimulate separatism. This has led to a number of disputes, including those concentrated in the densely populated Farghona Valley. Kyrgyzstan has seven enclaves within its borders; two are 
Tajik and five are Uzbek. The larger Tajik enclave is Vorukh and the largest Uzbek enclave is Sokh. Vorukh has a river running through it that both the residents of the enclave and the residents of the surrounding area in Kyrgyzstan threaten to cut off periodically when things get rough.

Resolution of border disputes and cooperation on border control is of utmost importance to these countries in order to make regional trade more efficient and more profitable and to have stability in the region. While recognizing that this is a sensitive issue as national interest are involved and no country would like to give up its territory, agreements must be made. Some progress has been made by the Central Asian states on this issue since the inception of the SCO and its predecessor the Shanghai Five. Central Asian leaders share a common commitment to preserving existing Soviet-era borders and reject nationalist or separatist claims, which has primarily contributed to stability in the region. Kazakhstan's border negotiations with Kyrgyzstan went relatively smoothly, and by 1996 the two had largely completed delimiting the border. Demarcation was finalized in December 2001, despite opposition from some government opponents.

Disputes in the Uzbek-Kyrgyz border, the most contested frontier in the entire post-Soviet space, although not yet resolved, have reportedly improved as Uzbekistan demined its side of the border, which had been mined by the Uzbek army in 1999-2000 to prevent incursions by religious extremists. Additionally, Uzbekistan is currently working to demine the Uzbek-Tajik border ( Kimmage 2005 ) Although Uzbekistan agreed to demine the borders at a special meeting of the Permanent Council of the Organization for Security and Co-operation in Europe (OSCE) in Vienna in 2004. Analysts in Central Asia and Russia believed that Uzbekistan made this decision not because of pressure from the OSCE, but because of the earlier summit of the heads of state of members of the SCO, held in Tashkent, which speaks to the effectiveness of the SCO ( Yegorov 2004).

Another difficulty in need of regional cooperation is the distribution of water resources. The region's water resources mainly come from two rivers, the Amu Darya and Syr Darya, which originate in Kyrgyzstan and Tajikistan and flow into the Aral Sea located in the territories of Kazakhstan, Turkmenistan and Uzbekistan. The Aral Sea basin supports seventy five percent of Central Asia's population and contains ninety percent of the region's surface water ( Horsman 2001: 70 ). Agriculture is the foundation of the region's economy and thirsty crops such as cotton and rice require intensive irrigation. In 1960, a decision was made to divert the Amu Darya and Syr Darya rivers to cotton plantations in order to boost their production, thus causing what the U.N. called the worst man-made environmental disaster in the world - the reduction of the volume of water in the Aral Sea by seventy five percent. To this day, Uzbekistan continues diverting the rivers, further damaging the sea, and because it uses antiquated Soviet irrigation practices and technology, over fifty percent of the water gets lost in transit to the agricultural fields. In Kazakhstan, however, the situation is 
improving, with the construction of a thirteen kilometer dam that split the Northern part of the sea from the southern part (Uzbekistan's portion), allowing the return of forty percent of the water back to the sea. The dam was part of a $\$ 68$ million project, financed by loans from the World Bank. In 2007, Kazakhstan secured a $\$ 126$ million loan and plans to build a second dam, which they hope will bring the water back to the port of Aralsk ( Antelava 2007).

The water distribution problems can be traced back to Soviet times when the water and energy resources were exchanged freely across what were only administrative borders, and Moscow provided the funds and management to build and maintain infrastructure. Since independence, the Central Asian states have failed to come up with a viable regional approach to replace the Soviet system of management. The existing water agreements allocate seventy three percent of waters from the Aral Sea Basin to Kazakhstan, Turkmenistan and Uzbekistan, whereas Kyrgyzstan and Tajikistan - countries with ninety percent of all water - are assigned less than a quarter of the water for their own needs (in exchange of energy resources) (Stuart. 2001). Moreover, although downstream countries in the region believe that water is a shared resource for the whole region, they do not take responsibility for maintaining the water systems. Temir Sariev, deputy in the Kyrgyz parliament, told Asia Water Wire, a reporting agency on water issues, that "The power complex of the country is worn out. During the [country's] fifteen years of independence, modernization has not been carried out. We spend huge amounts of money on the maintenance and repair of reservoirs. But our neighbors - Uzbekistan and Kazakhstan - use water free of charge" ( Kabulov 2006 ).

The Central Asian states have tried to build a framework for water cooperation, creating the International Fund for Saving Aral Sea and the Interstate Water Coordination Water Commission, but failed to sustain the dialogues they started. Central Asian governments continue to sign water agreements annually, but most of them are not carried out. Unfortunately, not much cooperation was achieved through the SCO, either. Although there was some talk of hydropower cooperation at the 2007 SCO summit in Bishkek, the organization did not show much interest in dealing with the existing problems in the energy sector among its smaller member states such as Kyrgyzstan or addressing Tajikistan's strained relations with Uzbekistan ( Marat 2007).

\subsection{Balancing Regional Powers}

Kazakhstan, Kyrgyzstan and Tajikistan have perceived Uzbekistan's dominance and heavy-handed behavior as their greatest external threat, and it is this challenge in particular that has shaped the ways in which they approach the regionalization process ( Bohr 2004: 489 ).

With the collapse of the Soviet Union, Russian influence in Central Asia started to fade away because the former concentrated on its internal problems such as economic and social crisis, depopulation, degenerating industrial infrastructure, and separatism in Chechnya. This turn of events left a power vacuum in Central 
Asia: Uzbekistan, with the strongest economy in the region at the time, the best infrastructure, and the largest military and population began to pursue its ambitions for regional dominance. Tajikistan and Kyrgyzstan were particularly vulnerable to Uzbekistan's aggressive behavior.

Tajikistan and Kyrgyzstan depended on Uzbekistan for fossil fuel energy resources and the latter has frequently played this card by shutting off natural gas pipelines in the middle of the winter over late payments and other disagreements, resulting in Tajik and Kyrgyz citizens freezing to death in their homes. Moreover, due to the geography of the region and the Soviet planning, Tajikistan is dependent on Uzbekistan for all overland and rail transport.

In the mid-1990s, Uzbekistan also played a significant role in the Tajik civil war, and in fact, the northern elites of Tajikistan prevailed in the civil war because of support and backing from Uzbekistan and Russia. Consequently, Uzbekistan and Russia maintained considerable influence over the course of internal Tajik politics, and neither state has behaved as if it considered Tajikistan a genuinely sovereign and independent country. Furthermore, Kazakhstan, Kyrgyzstan, and Tajikistan have suffered from Uzbekistan's introduction of a rigorous visa regime in 1999, which hampered regional trade, and the mining of the border regions in the same year, which caused many civilian deaths.

Consequently, Kazakhstan, Kyrgyzstan and Tajikistan found it beneficial to join the SCO as a way to deal with, and as a counterweight to Uzbekistan's aggressive behavior. Not only does the SCO maintain the balance of power among the Central Asian states, it also provides a way to balance the influence of the major neighboring powers - China and Russia. Understandably, the Central Asian states would like to avoid total dependence on one or the other power. As history shows, this region has been under the rule of a series of foreign powers. Indeed, Russia still has great influence in Central Asia as it controls many oil and gas pipelines that carry Kazakh oil and Uzbek natural gas to international markets, provides military assistance in Tajikistan and Kyrgyzstan as well as investments in their hydropower industry.

The Central Asian states are wary of China as well. China has, in fact, been injecting large financial investment into Central Asia, especially in Kazakhstan, paying more than market price for the acquisition of oil fields and the development of transportation networks, as well as calling for greater regional cooperation. This is a mixed blessing for the poorer Central Asian countries, as with greater prosperity may come greater dependence on China. Furthermore, throughout the 1990s and early 2000s, Central Asia became an attractive destination for temporary and permanent immigration from China, particularly from Xinjiang province. For instance, in Kyrgyzstan up to 120,000 Chinese immigrants have moved into the country in the past fifteen years, filling the gap in the consumer retail and service markets. Although, the Kyrgyz government has failed to acknowledge their presence, Chinese immigrants have already played an important role in the economic and social development of Kyrgyzstan. 
However, Chinese immigration is an issue that troubles both citizens and politicians in Kazakhstan and Kyrgyzstan ( Abazov 2006 ).

\section{CONCLUSION}

The SCO goals seem to be compatible with the Central Asian states' interests and it has made efforts towards satisfying them. In the political sphere, the SCO has stressed non-interference in domestic affairs of sovereign states by foreign nations and support for each member state's right to choose its own path of development. Additionally, in the wake of the Tulip Revolution in Kyrgyzstan and the popular uprising in Uzbekistan of 2005, Central Asian leaders expressed appreciation for Beijing's and Moscow's support for their regimes and understanding of the need to suppress any opposition movements - whether democratic or Islamic - within their respective countries. The SCO addressed Central Asian states' economic interests by providing a forum for discussion of building trade, transit and transport systems in the region as well as energy and tourism development.

The member states have talked about setting up an "energy club" and a freetrade zone that local economists believe would benefit Central Asian consumers, although at this time Central Asian products are not ready to compete with Chinese goods. Since the inception of the SCO, economic relations among the member states have rapidly increased, close to ten-fold in eight years from 1997 to 2005 . To address security concerns, the SCO created RATS and conducts yearly joint military exercises. Furthermore, out of all the cooperation organizations that Central Asian states have created or joined, the SCO has been the most successful in increasing regional cooperation, especially in the transit and transportation arena. The SCO Forum began functioning in 2006 with the goal of increasing multilateral cooperation in environmental protection, culture, education and sports and has been relatively successful as these are not controversial areas.

It is in the interests of the Central Asian states to continue the multidirectional policy towards the major powers that have expressed willingness to develop and secure Central Asia. No major power single-handedly has been able to satisfy all of Central Asian needs, nor do the Central Asian states want a total dependence on one power. It seems clear that, Central Asian leaders will continue to exploit major power differences and sell their cooperation to the highest bidder. Most importantly, multidirectional foreign policies have allowed Central Asian leaders to pursue their national (and personal) interests.

\section{REFERENCES}

ABAZOV, Rafis ( 2006 ), "Chinese in Central Asia: Loyal Citizens or Fifth Column?" Central Asia-Caucasus Analyst, February 8, 2006, http://www.cacianalyst.org/view_article.php?articleid=3987 (Accessed April 2009). 
ANTELAVA, Natalya ( 2007 ), "Dam Project Aims to Save Aral Sea," BBC News, April 9, http://news.bbc.co.uk/2/hi/asia-pacific/6538219.stm (Accessed May 2009).

AMNESTY INTERNATIONAL ( 2006 ), Amnesty International Report 2006, (Amnesty International: British Section, http://web.amnesty.org/report2006/index- eng (Accessed March 2009).

ASIAN DEVELOPMENT BANK ( 2002 ), "Technical Assistance to the Republic of Tajikistan for the Hydropower Development Strategy,", http://www.adb.org/Documents/TARs/TAJ/tar taj35153.pdf (Accessed Februrary 2009).

ASIAN DEVELOPMENT BANK ( 2005 ), "UNESCAP and ADB Assistance for SCO to Support Preparation of Regional Transport Agreement," CAREC Quarterly Newsletter, http://www.adb.org/Documents/ Periodicals/CAREC/newsletter- apr2005.pdf (accessed February 2009).

BEDDOES, Zanny Minton- ( 1998 ), "A Survey of Central Asia: a Caspian Gamble: Pipeline Poker," The Economist 346( 8054 ) : 3-18.

BLACKMON, Pamela ( 2005 ), "Back to the USSR: why the past does matter in explaining differences in the economic reform processes of Kazakhstan and Uzbekistan", Central Asian Survey, 24( 4 ) :391-404.

BLAGOV, Sergei ( 2002 ), "Shanghai Cooperation Organization Prepares for New Role," Eurasianet.org, April 29,

http://www.jamestown.org/programs/edm/single/?tx_ttnews\%5Btt_news\%5D=3 0616\&tx_ttnews\%5BbackPid\%5D=176\&no_cache $=1$ (Accessed April 2009).

BLAGOV, Sergei ( 2005 ), "Shanghai Cooperation Organization Summit Suggests New Russia-China Links," Eurasia Daily Monitor, July 6, 2(30). http://www.jamestown.org/programs/edm/single/?tx_ttnews\%5Btt_news $\% 5 \mathrm{D}=3$ 0616\&tx_ttnews\%5BbackPid\%5D=176\&no_cache $=1$ (Accessed April 2009).

BOHR, Annette ( 2004 ), "Regionalism in Central Asia: New Geopolitics, Old Regional Order," International Affairs, 80 ( 3 ) : 485-502

BOWERS, Stephen R; Musayev, Bakhodir; Samson, Steven Alan ( 2006 ), The Islamic Threat to Eastern Central Asia, The Journal of Social, Political, and Economic Studies,31( 4 ) : 375-397.

BRUMMER, Matthew ( 2007 ),"The Shanghai Cooperation organization And Iran: A Power-Full Union", Journal of International Affairs, 60 (.2 ): 185-198.

CHUNG, Chien-peng ( 2006 ), "China and the Institutionalization of the Shanghai Cooperation Organization", Problems of Post-Communism, 53 ( 5 ): 3-14. 
COHEN, Ariel ( 2006 ), "After the G-8 Summit: China and the Shanghai Cooperation Organization", China and Eurasia Forum Quarterly, 4 ( 3 ): 51-64

COHEN, Gregory Cohen ( 2005 ), "Collective Security and Non-State Actors in Eurasia", International Studies Perspectives, 6: 274-284

COLLINS, Kathleen (2007), "Ideas, Networks, and Islamist Movements Evidence from Central Asia and the Caucasus", World Politics. 60 (1): 64-96.

Daly, John ( 2005 ), "Sino-Kyrgyz Relations After the Tulip Revolution," Jamestown Foundation China Brief, June 7, http://www.asianresearch.org/articles/2614.html (Accessed May 2009).

DE HAAS, Marcel ( 2007 ),"The Shanghai Cooperation and the OSCE: Two of a kind?", Helsinki Monitor, 18 ( 3 ) :.246-259.

FREEDOM HOUSE PRESS ( 2006 ), "Freedom House Director of Programs Testifies on Freedom in Central Asia," April 26,

$\mathrm{http}: / / \mathrm{ww} w$.freedomhouse.org/template.cfm?page=70\&release=359. (Accessed May 2009).

HANKS, Reuel R. ( 2005 ), Central Asia: a global studies handbook, ABC-CLIO.

HORSMAN, Stuart ( 2001 ), "Water in Central Asia: Regional Cooperation of Conflict?" In Central Asian Security, (Ed.) Roy Allison and Lena Johnson ,Washington, DC: Brookings Institution Press.

KAY, Sean ( 2006 ), Global security in the twenty-first century: the quest for power and the search for peace, Lanham, MD: Rowman \& Littlefield.

KABULOV, Egamberdy ( 2006 ), "'Water War' Brewing on the Horizon?" Asia Water Wire, December 4, http://www.asiawaterwire.net/node/491 (Accessed March 2009).

KANDIYOTI, Rafael ( 2008 ), "What price access to the open seas? The geopolitics of oil and gas transmission from the Trans-Caspian republics", Central Asian Survey,27 ( 1 ):75-93.

KATZ, Mark ( 2006 ), "Revolutionary Change in Central Asia," World Affairs, 168 ( 4 ) :157-171.

KELLNER, Thierry ( 2004 ), The OSCE and the multiple challenges of transition: the Caucasus and Central Asia, ( Ed. Farian Sabahi, Daniel Warner ), Ashgate Publishing, Ltd.,

KENDZIOR, Sarah ( 2006 ), "Inventing Akromiya: The Role of Uzbek Propagandists in the Andijon Massacre", Demokratizatsiya; 14 ( 4 ). 
KIMMAGE, Daniel ( 2005 ), "Week at a Glance," Radio Free Europe/Radio Liberty Reports, 5, No. 43, November 10,

http://www.rferl.org/reports/centralasia/2005/11/43-101105.asp (Accessed March 2009)

KRASTEV, Nikola ( 2006 ), "Uzbekistan: Freedom House Becomes Latest NGO Casualty," Eurasianet.org, February, http://www.eurasianet.org/departments/civilsociety/articles/pp021306.shtml (Accessed April 2009).

LEE, Choong Y., Ekaterina Kolesnikova ( 2009 ), "FDI and Its Significance on Economic Development in Kazakhstan: Issues and Prospects", The Journal of International Management Studies, 4 ( 128 ):127-134.

LUBIN, Nancy ( 2004 ), "Who's Watching the Watchdogs?: Drug Trafficking in Central Asia," in In the Tracks of Tamerlane: Central Asia's Path to the 21st Century, ed. Daniel L. Burghart and Theresa Sabonis-Helf, Washington, DC: National Defense University.

LUKIN, Alexander ( 2007 ), "The Shanghai Cooperation Organization: What Next?" Russia in Global Affairs,2,

http://eng.globalaffairs.ru/numbers/20/1135.html (Accessed February 2009).

MARAT, Erica ( 2007 ), "SCO Summit Focuses on Energy Cooperation," Eurasia Daily Monitor, August 17, http://www.jamestown.org/edm/article.php?article_id=2372387(Accessed May 2009) .

MCDERMOTT, Roger ( 2003 ), "Shanghai Cooperation Organization Takes Significant Step Towards Viability," Eurasianet.org,

http://www.eurasianet.org/departments/insight/articles/eav090503b (Accessed April 2009).

MCGLINCHEY, Eric ( 2005 ) , Autocrats, Islamists, and the Rise of Radicalism in Central Asia ,Current History, 104 ( 684 ).

$\mathrm{NICHOL,} \mathrm{Jim} \mathrm{(} 2006$ ), "Central Asia: Regional Developments and Implications for U.S. Interests," Congressional Research Service Report for Congress, http://fpc.state.gov/documents/organization/ 76879.pdf (Accessed May 2009).

ÖKSÜZ, Suat ( 2009 ), " An Emerging Powerhouse In Eurasıan Geopolitics : The Shanghai Six+", Ege Academic Review, 9 ( 2 ): 713-734.

PANNIER, Bruce ( 2007 ), "Central Asia: SCO to Hold Largest Military Exercises to Date," Radio Free Europe/Radio Liberty, http://www.rferl.org/content/article/1078047.html (Accessed April 2009). 
PARAMONOV, V, , A and Khoshnazarov, S.( 2006 ), "Regional cooperation in Central Asia: A view from Uzbekistan (I)", Problems of Economic Transition, 49 ( 4 ) : 6-86.

POMFRET,Richard ( 2005 ), "Kazakhstan's Economy since Independence:Does the Oil Boom Offer a Second Chance for Sustainable Development?", EuropeAsia Studies, 57 ( 6 ) : 859 - 876

PORTER, Michael E. ( 2005 ), Kazakhstan's Competitiveness: Roadmap Towards a Diversified Economy, Almaty.

RADNITZ, S. ( 2006 ) ,"Weighing the political and economic motivations for migration in post-soviet space: The case of Uzbekistan", Europe-Asia Studies, .8 ( 5 ) : 653-677.

REPUBLIC of Uzbekistan Portal of State Authority, http://www.gov.uz/en/ctx.scm?sectionld=119\&contentld=1944 ( Accseed March 2009 )

RUfFIN, M. Holt ( 1999 ), Civil society in Central Asia, ( Ed. ) M. Holt Ruffin, Daniel Clarke Waugh, University of Washington Press.

RUMER, Boris Z. ( 1996 ), Central Asia in transition: dilemmas of political and economic development, M.E. Sharpe.

SAIDAZIMOVA, Gulnoza ( 2004 ), "Kazakhstan: Soros Foundation Says Tax Evasion Case is Politically Motivated," December 30,

http://www.rferl.org/featuresarticle/2004/12/c217e0f5-2512-4606-8d79-

8453f429e36e.html (Accessed April 2009 ).

Sakiev, Marat ( 2006 ), "International Water Resource Management: Division of Hydro Resources between the Kyrgyz Republic and Republic of Uzbekistan," Presentation by National Agency of the Republic of Kyrgyzstan,

http://www.narucpartnerships.org/Presentations/Kyrgyz/oct06/NAAPDC/Sakiev International\%20management\%20of\%20hydro\%20resources\%20between $\% 20$ KG\%20\&\%20UZ eng.pdf (Accessed March 2009).

SCHRI, Daan van der ( 2005 ), "The IMU: Fish in Search of a Sea," Eurasianet.org, http://www.eurasianet.org/departments/insight/articles/ pp031405.shtml (Accessed March 2009).

SPLIDSBOEL-HANSEN, Flemming ( 2000 ), "GUUAM and the Future of CIS Military Cooperation”, European Security, 9 ( 4 ) : 92-110

The World Bank, Country Brief (2009),

http://www.worldbank.org.kz/WBSITE/EXTERNAL/COUNTRIES/ECAEXT/KAZ AKHSTANEXTN/0,,contentMDK:20629270 menuPK:361877 pagePK:141137 piPK:141127 theSitePK:361869,00.htm ( Accessed march 2009). 
UNITED NATIONS ( 2008 ), International Instruments Related To The Prevention and Suppression Of International Terrorism, United Nations Publications.

UNITED NATIONS, World Drug Report ( 2008 ), United Nations Office on Drugs and Crime, Vienna, Austria: United Nations,

http://www.unodc.org/documents/wdr/WDR_2008/Executive\%20Summary.pdf (Accessed April 2009 ).

U.S. ENERGY INFORMATION ADMINISTRATION, Country Analysis Brief, May 2009,http://tonto.eia.doe.gov/country/country_energy_data.cfm?fips=UZ (accessed May 2009).

U.S. FEDERAL RESEARCH DIVISION ( 2007 ), "Country Profile: Kyrgyzstan," http://lcweb2.loc.gov/ frd/cs/profiles/Kyrgyzstan.pdf (Accessed March 2009).

U.S. FEDERAL RESEARCH DIVISION ( 2007 ), "Country Profile: Tajikistan,", http://lcweb2.loc.gov/ frd/cs/profiles/Tajikistan.pdf (Accessed March 2009 ).

VERME, P. ( 2006 ), "Macroeconomic policies and social unrest in Uzbekistan", Post-Soviet Affairs ,22 8 3) : 276-288.

WANG, Gungwu ( 2008 ), Yongnian Zheng, China and the new international order, Routledge.

YEGOROV, Yuri ( 2004 ), "Uzbekistan Agrees to Remove Minefields Along its Border with Kyrgyzstan," Eurasia Daily Monitor, 1 ( 41 ) ,June 29,, http://www.jamestown.org/

publications_details.php?volume_id $=401$ \&issue_id $=3001 \&$ article_id $=2368167$ (Accessed March 2009).

ZARDYKHAN, Zharmukhamed ( 2002 ), "Kazakhstan and Central Asia: regional perspectives", Central Asian Survey , 21 ( 2 ) :167-183.

ZARIFI, Hamrokhon ( 2007 ), "Hydro Energy Potential of Tajikistan; Present and Future," Presentation on regional cooperation in the sector of power and communications for the working group on economic cooperation in the framework of the 'Central Asia + Japan' dialogue,5 January,http://www.tjus.org/ prezentatsiya Zaripova eng.pdf (accessed January 2007). 